\title{
U.S.'s Foreign Policy and Nation-State Building in Iraq
}

\author{
Ali Mohamadian \\ Department of International Relations, Science and Research Branch, Islamic Azad University, Tehran, Iran \\ E-mail: a.mohamadian22@yahoo.com
}

Received: July 5, $2011 \quad$ Accepted: July 20, $2011 \quad$ Published: January 1, 2012

doi:10.5539/ass.v8n1p236

URL: http://dx.doi.org/10.5539/ass.v8n1p236

\begin{abstract}
In recent years, the issue of war and USA's unilateral actions in Middle East strategic zone made numerous debates among researchers of international relations, politicians, and diplomats. This formed political literature emphasized on two issues: the first one is about the way war actions taking place and its legitimacy in countries, and the second and more important one is about efficiency of USA in establishing stability, security and facing its unknown consequences in considered countries. In this respect, Nation-State building can be viewed based on the second issue. This article deals with transformations and events based on Nation-State building after Saddam fell from power. The aim is to see to what extent USA got ahead the Nation-State building project and what issues threaten this project.
\end{abstract}

Keywords: Preemptive and preventive operations, Terrorism, Democratization, State nation making, Failed states

\section{Introduction}

The developments in 1990s were very seminal for US foreign policy bringing many new opportunities. Geographically, considerable changes which were affected by cold war, has mainly happened in parts of world with powerless or no central powerful governments. Most of these countries belong to the Middle East which have fragile constructions in all political, social, and security fields. Territorially, borders and geographical divisions are artificial and were formed based on imperialism policy rather than regional facts and without considering ethnical issues, races and religions of nations. This led to various disputes and conflicts among such countries. In social field, there are many problems among Middle East's countries including numerous trends and sometimes ethical, religious, and racial differences and ideological conflicts inside a country and between countries and politically, lack of legal and independent organs, presence of suppressive and authorized governments without internal legitimacy, lack of democratization and civic social organs and also lack of rational relationship among countries and nations, lack of national identity formation and disparate cultural construction and many other problems. Anyway, these countries were unable to move from their traditional source to modern stage in forming an integrated and stable unit in framework of state nation making. For this reason, these countries are called Failed States in political literature.

The history of Nation-State building in foreign policy of the USA goes back to the post world war II period. Nation-State building can be known in more general design as a predominant radical change that is followed by the USA after termination of cold war and conversion in international system construction. In past, the main point to US was to keep balance and maintain its status against Union of Soviet. So, they didn't attempt to make any radical changes in countries. But after destroying the balance in favor of the USA, it attempted to perform Nation-State building in considered countries. The volume of the USA's action on Nation-State building format testifies this idea. Therefore, in forward decades Nation-State building will have special importance, particularly in strife regions and weak countries.

\section{Neoconservatives}

The election competition in 2000 was one of the most important elections in the USA. One aspect was George Bush's victory, but the important indicator in that period was the advent of new flow of opinions called "neoconservatives" in White House which assisted the evolution in administrative system. Definitely, the start of neoconservatives' performance was affected by their criticism of USA governments in 1990s (Bill Clinton's government) particularly in opposition to the USA's foreign policy in Middle East. Robert Kagan and William Krystal as conservative leaders believed that Clinton's governmental policies were inefficient. In 1998, along with 
other proponents including Donald Rumsfeld, Paul Wolfowitz, Richard Armitage, and Robert Zoellick, they wrote a letter to President Clinton in which they criticized his policies. In the letter they argued that the policy of "containment" of Saddam Hussein has been steadily eroding over the past several months... Our ability to ensure that Saddam Hussein is not producing weapons of mass destruction, therefore, has substantially diminished (Kagan and Kristol, 2005; 20).

Following this course, neoconservative groups depending on a comprehensive and pervasive theory, initiated to control political, economical, and military systems through Think Thank, such as US project for new century and Heritage foundation, newspapers, Weekly Standard, and numerous speeches and their origin ideological articles, by William Kristol and Richard Perle. Starting point of their movement emphasized on that the policies which Bush senior and Clintons followed in their government were anarchy and disordered ones and the only thing which can prevent US power reduction is return to policy followed by Reagan. His policy included splendid increase in defensive expenditure, establishment of a Missile Defense System and confronting threats made by dictators including China, Serbia, Iraq, Iran, and North Korea (Harman:1386 137-138). But then to new politicians of the USA, military power perpetuation and its manipulation in necessary issues are the first priority. In fact, for neoconservatives, military power is not only the basic currency of international politics but also the central vehicle for advancing American political values overseas. Military victory, by sweeping away tyranny, lays the foundation for democratic revolution; ... Indeed, central to neoconservative ideology is the perpetuation of American's postCold war, global military supremacy via-if necessary- unilateral preventive military action against rising potential enemies, especially so-called rogue states seeking to acquire nuclear weapons (Record,2010; 33-34).

Theoretically, two intellectual trends had more effect on Bush's government including neoconservatives and realists. After the fall of the Berlin wall in 1989, the differences between neoconservatives and realists were brought into even starker relief. Though both campus supported the first Gulf War in 1990-91, they diverged sharply in their opinions of its conclusion. Neoconservatives were indignant over (the first) President Bush's decision to allow Saddam Hussein not just to remain in power but to suppress, with characteristic brutality, the Kurdish and Shiite revolts inspired by the American invasion (Rosen,2005;3).

Due to such indefinite consequences, experts believe that the U.S. policies in 1990s had no specific identity. According to Charles Kruathammer, from the end of the Cold War until the terrorist attack of sept. 11, 2011, the United States took a ten-year "holiday from history." On the face of it, this seems a strange way to characterize American behavior during the decade. United States military forces were more active during these years than at any time since the the Vitnam War- in the Gulf and Iraq, in Somalia, in Haiti, in Bosnia, in Afghanistan, in sudan, in Colombia, and in Kosovo (Harries, 2005; 78).

According to Harries how the Bush administration's foreign policy would have developed in the absence of the sep. 11 attack, we shall never know. But in an instant the terrorists gave the country the clear purpose that it had previously lacked. That organizing principle came under the name of a "war on terrorism."(Harries, 2005; 79).

Recent analyses all indicated that foreign policy of the U.S. at present age, is much different from past and especially from the era of cold war. Simons illustrates the general image of the new era as follows: The shaping forces in the modern world are easy to identify: the economic and military power of the United States; the growing resentment in the Muslim world, confined to authoritarianism and exploitation; the tension between religions and cultures; an expanding globalization of trade and technology; a growing internationalism among oppressed people around the world. In this context it seems obvious that in the short-to- medium term American power will remain unassailable...It is inevitable that American aggression will stimulate a response, not only in the Muslim community but in the wider world also (Simons,2003;12).

Based on Samuel Huntington, in this unique multi polar world, superpower turns to unilateral actions and by making tension and clash particularly with regional great powers, they attempt to enforce its volition. US endeavored or it seems that in spite of many other difficulties, it strived to act unilateral (Huntington, 44:1383). According to Rosen, the Bush Doctrine, with its combination of military assertiveness and democratic idealism, many have been declared in the wake of $9 / 11$ (Rosen, 2005; 1). September 11 shocked the nation, and it shocked the president (Kagan and Kristol, 2005; 25).

Podhoretz (2005) declares:

1). The first pillar of the bush Doctrine, then, was built on a repudiation of moral relativism and an entirely unapologetic assertion of the need for and the possibility of moral judgment in the realm of world affairs. (p. 121)

2). The second was an equally dramatic shift in the conception of terrorism as it had come to be defined in standard academic and intellectual discourse. (123). 
3). The third pillar on which the Bush Doctrine rested was the assertion of our right to preempt. (126).

4). One would think that George W. Bush had been ignoring "the Israeli-Palestinian conflict" altogether in his misplaced "obsession" with Iraq. (132). (Podhoretz, 2005; 121-123-126-132).

Notwithstanding all theoretical outlooks on about Bush's Doctrine, practically and particularly in Middle East, this Doctrine manifested in three subjects. In other words, the neoconservatives' sovereignty over White House completely transformed practical patterns of US foreign policy. Definitely, the new atmosphere created in US diplomacy system has had the most impact on new strategies on other events which happened in late 20th century such the Union of Soviet disruption and in early 21 th century, such as the September $11^{\text {th }}$ event.

\section{Preemptive and Preventive's Operations}

One of the foreign policies in Middle East is to apply military tools for preemptive and preventive war. Maybe Bush's statement that "we meet here during a crucial period in the history of our nation, and of the civilized world. Part of that history was written by others; the rest will be written by us" (Fukuyama, 2006; 1) is the best document to help realize the viewpoint of the U.S. administration on forward developments. As Kesler declares, George W. Bush's first presidency, devoted to compassionate conservatism and to establishing his own bona fides, lasted less than eight month. On September 11, 2011, he was reborn as a War presidency... The Bush Doctrine called for offensive operations, including preemptive war, against terrorists and their abettors- more specifically, against the regimes that had sponsored, encouraged, or merely tolerated any "terrorist group of global reach." Afghanistan, the headquarters of al Qaeda and its patron the Taliban, was the new doctrine's first beneficiary, although the president soon declared Iraq, Iran, and North Korea (to be precise, "states like these, and their terrorist allies") an "axis of evil" meriting future attention (Kesler, 2005; 222).

Preemptive and preventive as the fundamental bases of Bush security Doctrine, made numerous disputes among international relations theorists and even international lawyers. There are explicit conflicts in recent interpretations about legitimate application of concept of force, particularly about conceptions of imminence threats. The first is that there is no distinct criterion that the threat is imminence and impending. In other words, there is no explicit criterion like what is stated in Article 51 of the charter of United Nation Organization (armed attack). Therefore criteria are mental and thus, each country based on its interest gives different reasons for forward threats.

Second, it is not clear how to establish a logical and positive relationship between possessing or accessing exotic weapons and invasion to other countries. Obviously, each country has different justifications in response to such questions. Thus, actually according to the issues mentioned, achieving a reasonable framework acceptable to all can be difficult. Other weaker countries would not have the same ability as powerful countries to respond to the threats for self-defense. These countries want the "force" to be interpreted according to the Article 51, because they may be attacked by those countries that want the force" to be used in expanded interpretation in the Charter are. Therefore, they support the UN collective action toward the expanded interpretation. The United States wants to expand the use of force is in the form of unilateral action against other countries. Although governments and international bodies considered such an interpretation in contrary to the principles of international law, but this doctrine was used in operations in Afghanistan and Iraq.

\section{War on Terrorism: A New Identity of U.S. Foreign Policy}

Preemptive and preventive war of George W. Bush addressed two parties. First and specifically the terrorist groups that threaten U.S. interests and its allies and second, countries that are harboring any kind of such groups. Different analysis on applying this aspect of terrorism as a security threat has been made. One aspect was on the downfall of USSR in the 1990s. In this decade, U.S. foreign policy for the integration and implementation in some areas had no contact or addressee and American diplomacy in this decade, had no particular identity. Americans have always looked for competitors to formulate foreign policy in this period. Although in the present, the reality of the threat from terrorist groups is acceptable, but there is no criterion for dealing with such threats and American officials faced it with a free hand. While in the past, there had also been such threats to the United States. Podhoretz in an article titled "World War IV" stated that Bin Laden was not the first enemy of a democratic regime to have been " emboldened by such impressions (Podhoretz, 2005; 113).

While offering opinions on war on terrorism, some other issue was set forward as weak, fragile and failed states which led to formation of fundamentalist groups and promotion of violence among nations of such countries. Westerns made following statements on failed countries:

"1. brutalize their own people and squander their national resources for the personal gain of the rulers;

2. display no regard for international law, threaten their neighbors, and callously violate international treaties to which they are party; 
3. are determined to acquire weapons of mass destruction, along with other advanced military technology, to be used as threats or offensively to achieve the aggressive designs of these regimes;

4. sponser terrorism around the globe; and

5. reject basic human values and hate the united states and everything for which it stands."(Record, 2010; 51).

Failed countries also faced some internal problems. By definition, diminished states are unstable. Lacking a strong central government, adequate army and police, as well as an effective rule of law, the environment of lawlessness and its consequences inhibits society. As violence spirals from ethnic tension to sectarian violence and on to full-scale civil war, the instability usually bleeds beyond borders. One state's mayhem and bloodshed spills over to neighbors, creating regional instability that threatens the broader interests of the neighborhood, and of America... Weak, failing, and failed states are fertile ground for terrorism. Such states invariably are impoverished societies with little economic or social opportunity (Williamson, 2007; 14).

What seems to concern the United States over the September 11 attacks is undermining the attitudes of Americans about their safety. Due to their remoteness from other parts of the world, distance and two oceans around the borders, they have had no security threat in their minds. This attack was a valid line on the idea that Americans could benefit from the security forever due to their geographical position. Although in mid twentieth century, Americans were concerned about nuclear weapons technology and ballistic missiles, but the technology was in the hands a specific country, the behavior of which was predictable for the U.S. government and possible to manage respectively. But the main problem of terrorism is that they could not be placed in framework of Nation-State building and due to their network actions and their fundamental ideology to oppose and fight the U.S., America is indeed in difficulty.

\section{Democratization}

Democratization and making reforms are of the U.S foreign policy in the Middle East. Bush on September 7, 2003 had declared" "In Iraq, we are helping ... to build a decent and democratic society at the center of the Middle East. ... The Middle East will become a place of progress and peace.” (Record, 2010; 110).

Democratization or democracy making is now a serious challenge in relations between the U.S. Arab countries in the Middle East. This policy of the U.S. comes from their belief that failed states and rogu states constitute the biggest threats to world peace in the foreseeable future (Boot, 2005; 93).

There are many contradictions in the process of implementing democracy in the region. Much of the need for democratization in the region is due to the failed government as well as the growth of fundamentalism in the region in terms of terrorism. The attitude of the American leaders of the democracy-building is the long-term deal with the roots of terrorism and they suppose they could fight it by implementing necessary reforms. The reality is that democracy aiming to create permanent stability and implementing law and discipline in the region, is facing major problems in practice. Most Arab governments have non-democratic structure. So Arab leaders consider policy-making democracy as a factor for instability and eventually collapse their several decade-old governments in their countries. In fact, they are concerned about their continued ruling, the subject which political developments in early 2011 in the Middle East and North Africa (Tunisia, Egypt, Libya, Bahrain, Syria, Yemen, and even in emerging Iraq) confirmed its accuracy.

Certainly, the policy of democratization was formulated by this pre-assumption that after September 11, 2001, it became clear that weak or failed states could sponsor terrorism that threatened the core security interests of the world's sole superpower, the United States.... Although conventional military power was sufficient for some purposes, such as expelling Serbian military forces from Kosovo or defeating Saddam Hussein's army, the underlying problems caused by failed states or weak governance could only be solved through long-term efforts by outside powers to rebuild indigenous state institutions."(Fukuyama, 2006; 2)

In a conference at military institute of Virginia on April 17, 2002, Bush had stated in regard with the necessity of democratization that "we know that true peace will only be achieved when we give the Afghan people the means to achieve their own aspirations. Peace will be achieved by helping Afghanistan develop its own stable government. Peace will be achieved by helping Afghanistan train and develop its own national army. And peace will be achieved through an education system for boys and girls which works. We're working hard in Afghanistan. We're clearing minefields. We're rebuilding roads. We're improving medical care. And we will work to help Afghanistan to develop an economy that can feed its people" (Williamson, 2007; 12).

In this regard, Douglas Feith believes that the aim of democratization was always secondary to removing both Saddam Hussein from power and his threatening WMD "programs," and he chides president Bush for dropping the 
threat rational for the war once it becomes clear that no claimed stockpiles of Iraqi WMD existed. (Record, 2010; 108).

Evidence of recent decades was not a clear response to the above hypothesis. Terrorist acts in recent years has had an ascending trend. These operations were carried out In Iraq, Afghanistan, Iran, Pakistan, India and other countries. Certainly, the growth of Islamic fundamentalism was not in demand for democracy as by giving democracy to their governments, this trend would stop. Terrorist groups like Al Qaeda, not only do not want democracy, but they bring added pressure on their government to fight the Islamic and Western democracy. This is not clear whether the formation of democracy in the region is retreating such forces or terrorist groups will be emboldened to fight their governments.

So far, three types of behavioral patterns or strategies in the United States have occurred in the region: First, combating terrorism and second, preventive and preemptive war and third, fundamental reforms in the form of democracy. Of course, these three behaviors are all interrelated and should be benefitted as a compound behavior. For example, in Afghanistan, war on terrorism was implemented by this assumption that a failed state (Afghanistan) would make fundamentalism to grow in terms of terrorist groups (Al-Qaeda). Thus, initially removing such groups and then making change in political structure and implementation of political reforms (democratization) in order to eradicate terrorism were implemented.

\section{The United States and New Iraq (From Being Overthrown to Reconstruction)}

The relationship between the United States and Iraq in 1990, according to the policies of containment and sanctions, as we were witnessing, was registered. This decade faced with war with Iraq and the withdrawal of Iraqi troops from Kuwait in 1991 and following that the implementation of policy of containment and sanctions. Conflict between the two countries brought many ups and downs. With the victory of George Bush and the settlement of neoconservatives in the White House, the past policies toward Iraq were criticized. New U.S. administration interpreted the foreign policy of the country on Saddam's regime as being inefficient and considered it as wasting resources, energy and time. Associated with the coalition led by Britain and the United States and with cooperation of more than 30 countries, on March 20, 2003, the war against Iraq began. On April $9^{\text {th }}$, the coalition forces occupying Baghdad, the capital of Iraq, toppled Saddam's government and the war ended.

Immediately after the end of major operations in the war, stabilization of the situation and the process of transferring power by U.S. forces began in Iraq. However, there was no UN agreement and consensus about the assignment and transfer of power to Iraqi leaders in the United States on the one hand, and the governments of Russia, France and Germany on the other hand. Even this situation was also matching the local agencies in the Bush Administration. In the same respect, the document made on January, $7^{\text {th }} 2003$ (before the war) in the UN by humanitarian approach in Iraq set a task for the first 100 days titled "Roadmap for Reform" (Road Map for Reform). This included the following key cases:

"1. Devise and implement a transitional justice policy addressing past violations in conformity with UN human rights standards.

2. Clarify the applicable legal framework to ensure consistency with international human rights law.

3. Carry out a review of existing laws and judicial structures, and a survey of the justice system.

4. Launch a national mechanism for rebuilding the justice system.

5. Establish a national human rights institution.

6. Vet and reconfigure existing law enforcement and corrections institutions.

7. Establish a strategy for rebuilding an appropriately-sized security sector under civilian control and protective of human rights.

8. Identify training needs and implement a training programme for justice personal.” (Simons, 2003; 63-64)

Of important concerns on the way was the concern for human rights. However, the tension among the UN, America and England has been existed. In early April 2003 Colin Powell, US secretary of state, emphasized that he would be talking to Kofi Anan about the appointment of special representative to supervise humanitarian aid, but stressed that the UN's political role was uncertain: We all understand the UN must play a role, but the nature to be seen. American and its coalition partners would play the leading role to determine the way forward (Simons, 2003; 62-63).

The first step for the U.S to initiate a new era in Iraq was that a Coalition Provisional Authority (CPA) to be responsible for the Iraq security, so that political leaders and people could settle the Iraqi government in the 
country. The U.S government appointed two representatives to supervise the CPA. By mid-February 2003 it was obvious that ex-General Jay Garner would become the effective governor of Iraq after the fall of Saddam. The 64-year-old Garner, who had led Operation provide Comfort to help the fleeing Kurds at the end of the 1991 Gulf War... Garner was known to be closely linked with a group of Washington Hawks....he was well prepared to arrange Iraqi recognition of Israel after the fall of the Saddam regime" (Simons, 2003; 78-79). Also, Garner established a good working relationship with many of Iraq's communal leaders (Stansfield, 2005; 150). Obviously, Garner's duty was to reconstruct Iraq, remove people working for Baath and building a new government. He met all this by establishing the Office of Reconstruction and Humanitarian Assistance.

"General Garner and the ORHA were replaced by Ambassador L. Paul Bermer III and the Coalition Authority (CPA) on 12 may 2003.... Bermer outlawed the Ba'ath party and purged nearly 100,000 people from the newly formed offices of government of ex-Ba'ath party personal. He also disbanded the Iraqi Army, putting 400,000 soldiers on the street civilian unrest was targeted by US military forces as the United States sought to establish security in Iraq by the barrel of a gun. The result was quite predictable- anti-occupation sentiment was heightened and militant activity increased."(Stansfield, 2005; 151)

Spending 10 million dollars within six months, Bermer established the foundation of democracy in Iraq. His comprehensive program included following items:

"1. train and assist Iraqi political parties, women's groups, youth group, and other civic organizations.

2. found civic education efforts in support of democratic values, the constitutional process, and the November 15 agreement.

3. build up the production facilities and professional capacity of the mass media.

4. support the caucuses that would select the transitional national assembly by the end of May 2004.

5. help recruit, staff, and train a new electoral administration for Iraq.

6. provide training and technical assistance to the transitional assembly as well as the provincial and local governments (Diamond, 2005; 71-72).

In addition to the above actions, Bermer took following actions to create stability and reduce conflicts:

"1. the creation of a task force to compensate victims of the previous regime( with an endowment of $\$ 25$ million from Iraq's oil income)

2. a far- reaching anti-money laundering act, running to sixteen pages and twenty-six articles, to criminalize the financing of crime and terrorism and the illegal transfer of money.

3. a sixty-eight-pages law(with 108 articles) to "comprehensively establish a safe, sound, competitive, and accessible banking system" for Iraq.

4. a financial management law establishing another "comprehensive framework" for the Iraqi government to conduct fiscal and budgetary policy and report on its activities" in line with international best practices.

5. the establishment of an ombudsman to hear appeals and protects on penal and detention matters.

6. the creation of a joint detainee committee, composed of representatives of the (predominantly American)Multinational force, the Iraqi interim government, and the American and British Ambassadors, to coordinate on all matters relating to the management of' Iraqi susoects detained by the Multinational Force.

7. a Political Parties Law establishing the legal basis for political parties, their equality before the law, and the electoral commission's authority over them.

8. the long-awaited order(Number 91) on the regulation of Armed Forces and Militias Within Iraq (Diamond,2005;273-274).

Almost two months after the fall of Baghdad, the second major step was taken to stabilize the new situation in Iraq. Paul Bremer, Iraq's American governor citing the Security Council's Resolution 1483, formed a council consisting of 25 so-called "transitional Iraqi Governing Council" on 13 July 2003. The council in fact was the first official action taken by the forces in Iraq after the fall of Saddam. The transitional council members included 13 Shiite members, including Dr. "Ahmad Chalabi" and "Abdul Aziz Hakim", the Sunni Arabs including "Adnan Pachechi" the former Iraqi foreign minister and chairman of the Assembly of Independent Democrats, Kurds with five members including " Massoud Barzani", the leader of Kurdistan Democratic Party and" Jalal Talabani " theleader of the Patriotic Union of Kurdistan, a Christian member called "Junadem Joseph Knew", a 50-year-old engineer, a 35-year old member from the Iraqi Turkmen called Ms." Shengul Shapuk" were considered the prominent 
members of the council. However, before determining the council members a number of U.S. government had a variety of visions of how political authority would be reestablished in Iraq. Vice President Cheny and his Office, $\ldots$ and pentagon neoconservatives like Deputy Secretary Wolfowitz,... were looking to hand power over fairly quickly to Ahmed Chalabi, the best-known but also most controversial Iraqi exile opponent of Saddam's regime... The CIA had its own favored Iraqi exile leader, Ayad allawi, a former member of the Baath Party who had defected in the 1970s, survived an assassination attempt in London by Saddam's henchman, and attemted to organize coup attempts to overthrow... By some rumors, the state Department favored yet another Iraqi exile, Adnan Pachachi, a secular nationalist and a sophisticated, liberal thinker who had served as Iraqi's foreign minister and UN ambassador before the Baathists seized power in 1968 (Diamond,2005;28-29). Despite the differences between politicians and executive agencies in the Bush administration, In the case of Iraq, neo-conservatives believed a friendly democratic regime ... would be more likely to pursue moderate policies in the region... Further, a democratic Iraq would, the United States believes, become fully integrated in the world capitalist system and provide lucrative opportunities for American business (Mcmillan, 2005; 12).

The third step in Iraq, four months after the formulation of transferred Governing Council of Iraq, on November 15, 2003, determined how to transfer power and governance in Iraq. The Iraqi interim administration that was most important step was prepared to transfer power to Iraq at this time. In this law such issues as a timetable for transferring power, the coalition forces as occupiers of Iraq and other important issues in formulating the Iraqi Constitution that were considered. Finally, on March 8, 2004 the Iraqi interim government was signed by Council members of Transitional Government of Iraq in nine chapters and 62 Articles. The most important issues in this law was to identify Islam as a legislation source along with other resources, including fundamental rights and freedoms and democratic principles, emphasizing the preservation of territorial integrity in the recognition of borders and internal divisions (18 provinces of Iraq were approved), the system of government in the Federative Republic of Iraq, democratic and pluralistic, the recognition of Kurdish language and Arabic as official language of Iraq and autonomy of Kurdistan region in Iraq.

\section{The United States and Iraq: The Pattern of Nation-State Building}

The transformations in Iraq in 1990 and 2000 should be considered as a debate between U.S. foreign policy in the two governments of Bill Clinton and George W. Bush. The conflict between the two theorists of U.S. foreign policy on Iraq led to the activation of U.S. foreign policy in the Middle East. In 1990, the view of international liberals in America's diplomacy imposed a decade of political difficulties and sanction to Iraq. Inability and inefficiency in the Clinton administration's to control ambitious efforts of Saddam to control provided opportunities for American neoconservatives to gain power. In such situation, the moderating policy of previous U.S. government about global and local developments was left behind and instead, multilateral movements in dimensions of military and security with patterns of preemptive and preventive war against refractory (hardware) countries and patterns as democracy-building in failed states (software) were implemented.

"George W.'s foreign policy was also notable for the very early emergence of high-level splits, notably between Secretary of State Colin Powell's defense of multilateralism and the pugnacious 'American' of Donald Ramsfeld and the Vice-president Richard Cheney"(Dumbrell, 2005; 37).

Undoubtedly, the U.S. diplomacy in the era of George W. Bush (2001 - 2009) was influenced by the ideas of the neoconservatives. Despite the significant tension among Bush's statesmen, the developments in Iraq from the beginning of the recent century and especially during Bush's government should be considered as the product of neoconservativist viewpoints on the global policy of the U.S. With such an approach, the study of the current situation in Iraq can be an evaluation of for effectiveness and success rates of neoconservatives. "The rapid collapse of the regime of Saddam Hussein marked a defining moment for advocates of regime change.”(Plesch,2005;47).

However, removal of Saddam from power was not all aspects of the war in 2003 in Iraq and after that, Iraq became the scene of numerous conflicts among Iraqis, international institutions, major powers and the world public opinion. The war removed the illegitimate and murderous Saddam Hussein regime, at a cost in lives of thousands of Iraqis, significant numbers of coalition forces and other personal, thereby allowing terrorist group to enter and use Iraq as a battleground (Keohane, 2005; 74).

To state the rate of success for the Nation-State building in Iraq, we may need to select indicators. In this regard, three main indicators can be helpful in evaluating the state nation making. These include territorial indicators, indicators of integration and national cohesion and political stability indicators. Political, economic and social developments in Iraq, since Saddam's fall, has brought some hope for the future as well as bringing some negative effects in the process of transferring Iraq's past authoritarian regime to a democratic model. 
Iraq does not have a deep problem in terms of territorial aspect. Although, Iraq had strong disputes with its neighbors on border issues, but in recent period it did not have enough power to discuss such issues and could not claim to settle disputes against its neighbors as it did in the past. Accordingly, neighboring states had no claims on their border with Iraq and this process can help to stabilize the situation in Iraq. But in this case, the issue of Iraqi Kurdistan was an important matter which could make recognized international borders of Iraq undergo changes. Iraqi Kurds have always tended to have a national territory and the establishment of an independent Kurdish state in northern Iraq. If this happens, Iraq will face more bottlenecks. It should be acknowledged that although presently, the main priority of Kurd leaders is to stabilize the current situation as well as achieved situation in Kurdistan (autonomy) after the Iraqi invasion in Kuwait and the international integrated response to Saddam's, they are pleased currently. However, they still seem to tend to form a Kurd government and wait for international and regional opportunities to achieve their goal.

The new situation in Iraq is not very satisfactory about the creation of national solidarity and integrity as the key factors for the successful state nation making. Certainly and according to most analysts of Iraq issues, ethnic conflicts and disputes with religious and ethnic dimensions are the most powerful platforms for challenges in Iraq. Ethical issues and discrimination policies of previous rulers in Iraq not only deepened racial gap in the country, but also it made difficult for Iraqis to achieve a strong common national identity. Now that there is a need for a correlation and integration to stabilize and advance the process of state nation making, its deficiencies is objectively evident. The extreme dominance of Sunnis as minorities in the country which was the consequence of the wrong policies in the past, has now weakened the democracy of Iraq and has brought many challenges after the establishment of its government in 2006. These challenges were mainly of ethical nature and the size and quality of them were so considerable that affected the developments in Iraq since the fall of Saddam. Tactics used by militant elements in Iraq in terms of quantity and quality is remarkable. Considerably, these attacks are recognizable in following dimensions and methods:

"1. Attack the structures of governance and security by ideological, political, and violent means.

2. Create alliances of convenience and informal networks with other groups to attack the United States, various elements of the Iraqi interim government, the elected government, and efforts at nation-building.

3. Attack Iraqi elites and ethnic and sectarian fault lines; use them to prevent nation-building and governance by provoking civil war.

4. Strike at U.S. and other aid projects to undermine Iraqi acceptance of the MNSTC-I and the perceived legitimacy of the Iraqi government.

5. Exploit Arab satellite television as well as traditional media-Islamist movements and other insurgents learned how to capture maximum exposure in regional media, use the Internet, and above all, explit the new Arab satellite news channels.

6. Focus on large U.S. installations.

7. Attack the United Nations, NGOs, embassies, aid personal, and foreign contractor business operations.

8. Kidnap, kill, and intimidate women and cadres of foreign workers.

9. Kidnap, kill, and/or intimidate professional, Iraqi media, and members of the intelligentsia (Cordesman, 2006; 32-37).

Addressing all the details of internal rebellion in Iraq would lead to prolonged discussions. Important issue is that based on the actions of the United States and its allies, the Sunni having the monopoly of power in the past, lost their power. They had various debates about the cause of the U.S. invasion to Iraq. To Sunni, a conflict for whatever reason, its outcome is only one thing and it was losing power caused by the actions of the United States. Therefore, during these developments, the main goal of insurgents against U.S. forces was set in Iraq. In the next step, they all in suicide attacks and bombings in different cities targeted Shiite and Kurdish citizens of Iraq and tried to prevent the peaceful process of transition of power from the coalition forces to the Iraqi government as well as the process of stabilizing the situation by Iraqis. Discontent of Arab countries including Saudi Arabia with the transfer of power to Shiites from Sunnis also caused deterioration and then support from extremist Sunni groups by transfer of equipment and made militant people pass through the border of this country into Iraq. Among the mistakes the U.S. led coalition forces made in the first months after the end of major operations of war, was the dissolution of military institution and the police and security institutions. Thus, putting approximately 400,000 of Iraq's young men out of work, and was exacerbated by delays in engaging the labor force in the processes of state-building. Further, 60 per cent of the adult population was out of the work in the aftermath of the invasion (Rangwala, 2005; 165). These factors ultimately lead to dissatisfaction of the Sunnis as well as soldiers and 
officers dismissed and increasing security threats in the form of terrorist acts and led the situation toward Iraq's security in its general atmosphere and delay in the process of Nation-State building rather than to push towards consolidation in the country.

Security of public atmosphere in which citizens were more involved in disposal of security risks rather than being involved in their business activities has caused the time for Iraq to advance the comprehensive development to be wasted. The sociologist Andreas Wimmer indentifies two factors which encourage ethnic heterogeneity to promote competition and violence within nascent states. Firstly, no strong networks of civil society organizations develop prior to the introduction of the modern state, and secondly, the incipient state is weak and cannot enforce equality before the law, democratic participation, protection from violence and access to services, for all the citizen of the state (Stansfield,2005;138).

U.S. efforts in Iraq have been together with mistakes and failures. Anthony Kurdsman in an extensive research on the U.S. actions in Iraq has described the fundamental and tactical mistakes of the U.S. in Iraq. He counted a list of numerous mistakes. The most important of them include:

"1. A failure to accurately assess the nature of Iraqi nationalism, the true level of cultural differences, and the scale of Iraqi problems.

2. The failure to plan and execute effective broader information operations before, during, and after the invasion to win the "hearts and minds of Iraqis".

3. The failure to create and provide anything approaching the kind and number of civilian elements in the U.S. government necessary for nation-building and stability operations.

4. The failure to plan and execute efforts to maintain the process of governance at the local, provincial, and central level.

5. Overreliance on exile groups with limited credibility and influence in Iraq.

6. The failure to anticipate and prepare for Iraqi expectations after the collapse of Saddam's regime.

7. Miscalculating UN, NATO, and coalition support and transit through Turkey.

8. The creation of only a small cadre of civilian and military in the Office of Reconstruction and Humanitarian Assistance (ORHA).

9. The failure not only to anticipate the threat of insurgency and outside extremist infiltration, in spite of significant intelligence warning, but also to deploy elements of U.S forces capable of dealing with counterinsurgency, civil-military operations, and nation-building as U.S forces advanced and in the immediate aftermath of the collapse of the regime.

10. Replacing ORHA after the fall Saddam Hussien with Coalition Provisional Authority (CPA) and suddenly improvising a vast nation-building and stability effort."(Cordesman, 2006; xxi-xxii).

Despite all mentioned problems, the U.S defends the recent transformations in Iraq and Afghanistan. In this regard James, Kurth writes "The Bush administration and neoconservative writers have repeatedly cited the U.S successes in West Germany and Jaoan, but they have been notably silent about the large numbers of failures or disappointments elsewhere, particularly in the Caribbean basin and Central America. In addition, the 1990's were the decade of numerous attempts to bring democracy to the countries of the former Soviet Union and communist Eastern Europe. With the exception of Bosnia and Kosovo, these democratization projects did not involve military occupation by U.S. forces".(Kurth,2005;43).

Kurth makes a comparison between successful symbols of Nation-State building as West Germany and Japan and a new sample as Iraq based on three indicators as follows:

"1. A prior liberal-democratic experience. First, Germany and Japan (as well as Austria and Italy) actually had considerable experience with some version of liberal democracy only of decades before, during the 1920's between the first World War and the Great Depression.... With regard to this feature of prior historical experience, the contrast between West Germany and Japan in the late 1940's and Iraq (as well as Iran, Syria, and Saudi Arabia) today could not be greater. These latter countries have never been liberal democracies.

2. A greater foreign threat. Second, and probably more important, West Germany and Japan in the late 1940's each perceived a foreign threat that was even greater than the one posed by the U.S. occupation.... Of course, given the memory of the Iran-Iraq War of the 1980s and the close relations between the Shi'ite regime in Iran and the Shi'ite majority in Iraq, Iran would appear to pose a potential threat to Iraq. And given the long-standing hostility of the Turke to the Kurds, Turkey might also appear to pose a potential threat to Iraq. 
3. An ethnically homogenous population. Third, and probably most important, West Germany and Japan (and also Austria and Italy) were among the most ethnically homogeneous nations in the world.... From its creation in 1920, it has always been divided into three ethnic parts, the Sunni Arabs, the Shi'ite Arabs, and the Kurds.(Kurth,2005;44-46).

Based on Kurth, Iraq in the past did not match any of the criteria set by him. But the failure of Nation-State building project in Iraq also required other variables. The fact, it is too early to assess the project's success in Iraq. If everybody agrees on the success of state nation building in mentioned countries, it is because the statement was not made in 1950s, but it is made currently after passing six decades. So, to assess the success of Nation-State building we need more time. On the other hand, it is not reasonable to compare the success of Iraq with some standard symbols of state nation making, because basically the situations in the two kinds of states are different and each kind has different characteristics and experiences. It seems to be more logic to compare the success rate in Iraq with its previous condition and not with the success in other countries. The Nation-State building performed from outside the country (U.S.) can cause to start a proper process of state nation making, but a total rely on a foreign actor could not guarantee the success of the country. Nation-State building in addition to a foreign stimulator (U.S.) demands such conditions as the local people' needs, national integration, national identity and unity, etc. Obviously, it should be considered that Nation-State building is a hard work in the absence of domestic factors. Henry Kissinger believes that "Democracy must be rooted in domestic factors, it will thrive only where it reflects cultural, historical, and institutional backgrounds" (Kissinger, 2005; 51)

The history of transformations in Iraq shows that unfortunately, even the powerful governments which influenced Iraq in the past did never attempt to create such factors. Farid Zakaria writes about it: "We do not seek democracy in the Middle East -at least not yet. We seek first what might be called the preconditions for democracy... the rule of law, individual rights, private property, independent courts, the separation of church and state... We should not assume that took hundreds of years in the West can happen overnight in the Middle East (Podhoreatz, 2005; 155).

\section{Conclusion}

Ambitious plan of George Bush and his allies in the form of preventive war against Iraq in 2003 brought much debate among experts in international relations as well as other social sciences. The debate centered on the international legitimacy of the war against a sovereign country, its cause and consequences. In public view, the war is not recognized having the international standards. Nevertheless, and despite the warning from the international communities including the UN, the war started by the command of George Bush and as we saw, it processed forward.

Malik states that American, military power, duly helped by Britian, demolished the Taliban and the Baathist regime in Iraq, and sought to increase the pressure on Iran and Syria, further exacerbated anti-Americanism across the globe. Anti Americanism, political Islam and the weakening of the post-colonial state-based order- the three contemporary realities of an uneven world polity- have certainly acquired a new impetus, as has the debate on democracy (Malik, 2005: 202). However, most of the Arab world may hate America, but a disjointed yet palpable movement for reform has gathered strength (Cohen, 2005; 233).

Developments in the Middle East and North Africa early this year confirmed Cohen's hypothesis. But in Iraq, the U.S. military invasion led to the collapse of Saddam Hussein's Baathist dictatorship. The previous structure of Iraq also collapsed. Developments in 2003 to 2006 by the U.S. brought a new legal and social structure to Iraq. New order in Iraq was formed during the process of developing constitution and holding elections in recent years. The effect of measures of the U.S. in regard with the preventive war caused beginning of a proper process for Nation-State building in the country. During recent years, Iraq has made much progress in terms of territorial indicators and political stability. Despite the problems, Iraq is not facing serious challenges on these two indicators, but it seems Iraq for national solidarity and integration requires enough time and extensive planning. The index is now the strongest barrier to further the process of Nation-State building in this country. Charles Kessler uses an interesting interpretation in this case. He writes: "The human right to be free, in other words, does not guarantee the human capacity to be free. That capacity must be elicited and demonstrated,... The habits of heart and mind that, among other things, allow a people's "choice" to be guided by "reflection". (Kesler,2005;226).

No doubt that developments ahead of new Iraq were influenced by the people of this country to build a new era. Democracy and freedom is possible only with the will of the people of this country. Otherwise, the future prospects for Iraq can be dark and blurry. 


\section{References}

Boot, Max. (2005). Reality check/ in modern imperialism, In: Gary Rosen (ed), The right war? The conservative debate on Iraq. Cambridge university.

Cohen, Eliot A. (2005). A time for humility, In: Gary Rosen (ed), The right war? The conservative debate on Iraq. Cambridge university. http://dx.doi.org/10.1017/CBO9780511509896.022

Cordesman, Anthony H. (2006). Iraqi security forces. A strategy for success. Praeger security international (PSI).

Diamond, Larry Jay. (2005). Squandered victory: the American occupation and the bungled effort to bring democracy in Iraq, times books. Henry Holt and company. New York.

Dumbrell, John. (2005). Bush's war: the Iraq conflict and American democracy, In: Alex Danchev and john Macmillan (eds), The Iraq war and democratic politics. Routledge.

Fukuyama, Francis. (2006). Nation-building and the failure of institution memory, In: Francis Fukuyama (ed). Nation-building, beyond Afghanistan and Iraq. The John Hopkins university press.

Harries, Owen. (2005). The perils of hegemony, In: Gary Rosen (ed), The right war? The conservative debate on Iraq. Cambridge university. http://dx.doi.org/10.1017/CBO9780511509896.011

Huntington. (2004). Culture, Power and Democracy, In: Mark Platnr and Alexander Smaller (editors), Globalization and Democracy Power, translated by Cirrus Faizi and Ahmad Rashidi. Tehran, Kavir Publications.

Kagan, Robert and Kristol, William. (2005). The right war for the right reasons, In: Gary rosen(ed), The right war? The conservative debate on Iraq. Cambridge university.

Keohane, Dan. (2005). The united kingdom, In: Alex Danchev and john Macmillan (eds), The Iraq war and democratic politics. Routledge.

Kesler, Charles R. (2005). Democracy and the Bush doctrine, In: Gary Rosen (ed), The right war? The conservative debate on Iraq. Cambridge university. http://dx.doi.org/10.1017/CBO9780511509896.021

Kissinger, Henry. (2005). Intervention with a vision, In: Gary Rosen (ed), The right war? The conservative debate on Iraq. Cambridge university. http://dx.doi.org/10.1017/CBO9780511509896.005

Kurth, James. (2005). Iraq: losing the American way, In: Gary Rosen (ed), The right war? The conservative debate on Iraq. Cambridge university.

Macmillan, John. (2005). The Iraq war and democratic politics, In: Alex Danchev and john Macmillan (eds), The Iraq war and democratic politics. Routledge.

Malik, Iftikhar H. (2005). Afghanistan and Iraq: faied state or democracy on hold?, In: Alex Danchev and john Macmillan(eds), The Iraq war and democratic politics. Routledge.

Plesch, Dan. (2005). The neo-cons, neo conservative thinking since the onest of the Iraq war, In: Alex Danchev and john Macmillan(eds), The Iraq war and democratic politics. Routledge.

Podhoretz, Norman. (2005). World war IV: how it started, what it means, and why we have to win, In: Gary rosen(ed), The right war? The conservative debate on Iraq. Cambridge university.

Rangwala, Glen. (2005). The democratic transition in the Iraq and the discovery of its limitations, In: Alex Danchev and john Macmillan (eds), The Iraq war and democratic politics. Routledge.

Record, Jeffrey. (2010). Wanting war: why the Bush administration invaded Iraq. Potomac book, Inc.

Rosen, Gary. (2005). Introduction, In: Gary Rosen (ed), The right war? The conservative debate on Iraq. Cambridge university. http://dx.doi.org/10.1017/CBO9780511509896.001

Simons, Geoff. (2003). Future Iraq: US policy reshaping the Middle East. Saqi books. London.

Stansfield, Gareth. (2005). The transition to democracy in Iraq: historical legacies, resurgent indentities and reactionary tendencies, In: Alex Danchev and john Macmillan (eds), The Iraq war and democratic politics. Routledge.

Williamson, Richard. S. (2007). Nation - building: The Dangers of weak, failing, and failedstates. The whitehead journal of diplomacy and international relations. [Online] Available: winter/spring.www.journalofdiplomacy.org 